\title{
Nutrient Partitioning and Stoichiometry in Unburnt Sugarcane Ratoon at Varying Yield Levels
}

\author{
José M. Leite ${ }^{*}$, Ignacio A. Ciampitti ${ }^{2}$, Eduardo Mariano ${ }^{3}$, Michele X. Vieira-Megda ${ }^{4}$ and \\ Paulo C. O. Trivelin ${ }^{3}$ \\ ${ }^{1}$ Department of Soil Science, University of São Paulo, Piracicaba, Brazil, ${ }^{2}$ Department of Agronomy, Kansas State \\ University, Manhattan, KS, USA, ${ }^{3}$ Laboratory of Stable Isotopes, University of São Paulo, Piracicaba, Brazil, ${ }^{4}$ Department of \\ Agriculture, State University of Montes Claros, Janaúba, Brazil
}

\section{OPEN ACCESS}

Edited by:

Raul Antonio Sperotto, Centro Universitário UNIVATES, Brazil

Reviewed by:

Ryoung Shin,

RIKEN Center for Sustainable

Resource Science, Japan

Graham Bonnett,

Commonwealth Scientific and Industrial Research Organisation,

Australia

*Correspondence: José M. Leite

josemarcosleite@yahoo.com.br

Specialty section:

This article was submitted to Plant Nutrition,

a section of the journa

Frontiers in Plant Science

Received: 02 November 2015

Accepted: 24 March 2016

Published: 20 April 2016

Citation:

Leite JM, Ciampitti IA, Mariano E, Vieira-Megda MX and Trivelin PCO

(2016) Nutrient Partitioning and Stoichiometry in Unburnt

Sugarcane Ratoon at Varying Yield Levels. Front. Plant Sci. 7:466. doi: 10.3389/fp/s.2016.00466
Unraveling nutrient imbalances in contemporary agriculture is a research priority to improve whenever possible yield and nutrient use efficiency in sugarcane (Saccharum spp.) systems while minimizing the costs of cultivation (e.g., use of fertilizers) and environmental concerns. The main goal of this study was therefore to investigate biomass and nutrient [nitrogen $(\mathrm{N})$, phosphorus $(\mathrm{P})$, and potassium $(\mathrm{K})$ ] content, partitioning, stoichiometry and internal efficiencies in sugarcane ratoon at varying yield levels. Three sites were established on highly weathered tropical soils located in the Southeast region of Brazil. At all sites, seasonal biomass and nutrient uptake patterns were synthesized from four sampling times taken throughout the sugarcane ratoon season. In-season nutrient partitioning (in diverse plant components), internal efficiencies (yield to nutrient content ratio) and nutrient ratios $(\mathrm{N}: \mathrm{P}$ and $\mathrm{N}: \mathrm{K})$ were determined at harvesting. Sugarcane exhibited three distinct phases of plant growth, as follows: lag, exponential-linear, and stationary. Across sites, nutrient requirement per unit of yield was $1.4 \mathrm{~kg} \mathrm{~N}, 0.24 \mathrm{~kg} \mathrm{P}$, and $2.7 \mathrm{~kg} \mathrm{~K}$ per Mg of stalk produced, but nutrient removal varied with soil nutrient status (based on soil plus fertilizer nutrient supply) and crop demand (potential yield). Dry leaves had lower nutrient content (N, P, and K) and broader N:P and $\mathrm{N}: \mathrm{K}$ ratios when compared with tops and stalks plant fractions. Greater sugarcane yield and narrowed $N: P$ ratio $(6: 1)$ were verified for tops of sugarcane when increasing both $N$ and $\mathrm{P}$ content. High-yielding sugarcane systems were related to higher nutrient content and more balanced $\mathrm{N}: \mathrm{P}(6: 1)$ and $\mathrm{N}: \mathrm{K}(0.5: 1)$ ratios.

Keywords: Saccharum spp., nutrient uptake, nitrogen, phosphorus, potassium, biomass, internal efficiencies

\section{INTRODUCTION}

Brazil is the world's largest sugarcane (Saccharum spp.) producer, with approximately 9 million hectares (ha) cultivated for biofuel, sugar, and electricity production (UNICA, 2015). In the last decade, cultivated sugarcane area in Brazil increased by about 4 million ha, primarily in the Southeast and Midwest regions. The latter expansion was explained by the significant increase in bioethanol consumption by flex-fuel light-duty vehicles (Adami et al., 2012).

Abbreviations: CEC, cation exchange capacity; DAH, days after harvest; DAP, days after planting; DRIS, diagnosis and recommendation integrated system; GDDs, growing degree days; GPS, global positioning system; HI, harvest index; HSS, humic substances solution; NIE, nutrient internal efficiency; NUE, nutrient use efficiency; RIE, reciprocal internal efficiency. 
The increase in cropland area is growing in parallel with technology investments implemented by sugarcane growers, such as machinery for planting and harvest operations. Due to environmental, agronomic, social, and economical reasons, manual harvest with prior burning of sugarcane has been replaced by harvesters, where dry leaves and tops (developing leaves and meristem) are now left over the soil surface, representing an input from 10 to $20 \mathrm{Mg} \mathrm{ha}^{-1}$ year $^{-1}$ of dry biomass (Fortes et al., 2013; Leal et al., 2013; Trivelin et al., 2013). This new harvest system has been called "green cane management system," where $\sim 80 \%$ of the Brazilian sugarcane fields previously harvested by hand with burning are currently harvested without burning by harvesters (Leal et al., 2013). In São Paulo, largest sugarcane-producing state, the crop is cultivated in 4.7 million ha, and more than $85 \%$ of the total is mechanically green harvested (UNICA, 2015).

The adoption of the green cane management system coupled with other management practices (e.g., precision agriculture tools) may modify nutrient requirements for modern sugarcane cultivars. Traditional approaches to the mineral nutrition of sugarcane included a strong emphasis on yield with a focus on a balanced nutrition, economic productivity, and quality (Kingston, 2014). Balanced nutrition implies that all essential nutrients needed for proper growth and ripening of sugarcane are available (Kingston, 2014). Nitrogen (N) and potassium (K) are demanded in large amounts by the crop, ranging from 150 to $400 \mathrm{~kg} \mathrm{ha}^{-1}$ (Silva and Casagrande, 1983; Shukla et al., 2009; Oliveira, 2011; Mariano et al., 2016) for sugarcane yield varying from 70 to $180 \mathrm{Mg} \mathrm{ha}^{-1}$. Nitrogen is a major nutrient for plant growth and tillering processes (Kingston, 2014), while K plays a key role on osmoregulation, which is important for cell extension, stomata movement, and enzyme activation (Epstein and Bloom, 2005; Shukla et al., 2009; Kingston, 2014). Phosphorus (P) is also essential for tillering, root and shoot growth (Kingston, 2014). In highly weathered tropical soils, usually characterized by low nutrient availability, monitoring the fertility status and fertilizer (NPK) application are essential practices to achieve and sustain high sugarcane yield levels (Franco et al., 2011; Oliveira, 2011; Trivelin et al., 2013).

For sugarcane, the nutrient ratio concept (also termed as nutrient stoichiometry) is not a new tool for diagnosing nutrient imbalances. Beaufils and Sumner (1976) developed the DRIS to evaluate $\mathrm{N}, \mathrm{P}$, and $\mathrm{K}$ requirements of sugarcane irrespective of plant age. Imbalances of these nutrients can be detected by means of DRIS before a deficiency can be diagnosed securely by means of threshold values (Beaufils and Sumner, 1976; Meyer, 1981). However, nutrient ratios investigated were unstable. Nutrient ratios $(\mathrm{N}: \mathrm{P}$ and $\mathrm{N}: \mathrm{K})$ changed during the stage of sugarcane development (Meyer, 1981). This occurs, because there is a complex interaction and dynamics of these elements within the soil-plant system (Meyer, 1981; Shukla et al., 2009; Mariano et al., 2016). Besides this complexity, these studies did not properly address the role of the nutrient ratios relative to the sugarcane yield. Second, previous research on nutrient ratios (N:P and $\mathrm{N}: \mathrm{K}$ ) for sugarcane probably were carried out in fields harvested with prior burning, a different condition to the current and future scenario. More than $70 \%$ of the total organic matter and nutrients contained in the sugarcane straw are emitted to the atmosphere via burning prior manual harvest (Mitchell et al., 2000). Therefore, the straw layer left over the soil surface when the crop is mechanically harvested without burning represents a significant input of organic $C$ and nutrients to the soilplant system, which can result in long-term benefits for the sustainability (via $\mathrm{C}$ sequestration) and nutritional requirements (by decreasing fertilizer needs) of sugarcane systems (Trivelin et al., 2013). Likely, nutrient ratios correlate with sugarcane yield in the green cane management system, but further investigations are required for examining this new research area.

Brazil is one of the largest consumers of fertilizer, with a nutrient demand expected to rise in the foreseeable future (IPNI, 2015). However, the country strongly depends on the international fertilizer market, especially for $\mathrm{N}(78 \%)$ and $\mathrm{K}(90 \%)$. A feasible strategy to reduce this dependency is to increase NUE, measured as sugarcane yield to nutrient content ratio (so called "physiological efficiency"). Management options for improving NUE from a cropping system perspective must also consider both NUE components: nutrient recovery and physiological efficiencies (Cassman et al., 2002; Ciampitti and Vyn, 2012). In sugarcane, little is known about NUE for green cane management systems. Vieira-Megda et al. (2015) investigated the effect of fertilizer $\mathrm{N}$ sources and rates on sugarcane productivity, without documenting changes in biomass accumulation. Similar results were reported by Otto et al. (2013), where among six sugarcane N-response trials, only one site showed high yield response $(>25 \%)$ to fertilizer N. Probably, lack of adequate balance on nutrient ratios ( $\mathrm{N}: \mathrm{P}$ and $\mathrm{N}: \mathrm{K}$ ) can act as yield-limiting factor in the green cane management system. Nutrient balances can help in closing yields gaps and improve NUE. Therefore, plant nutrient ratios are valuable tool for diagnosing crop nutrient imbalances (Ciampitti and Vyn, 2014). The aim of this study was to investigate and synthesize information on biomass and nutrient $(\mathrm{N}, \mathrm{P}$, and $\mathrm{K})$ content, partitioning, stoichiometry, and internal efficiency indexes in sugarcane ratoon at varying yield levels at three site-years.

\section{MATERIALS AND METHODS}

\section{Site Characteristics and Sugarcane Genotypes}

Three N-response trials for sugarcane fertilization were carried out in the state of São Paulo, Southeast region of Brazil. Two site-years were performed during the 2009/2010 growing season (Sites 1 and 2), while the remaining experiment (Site 3) was conducted in the 2012/2013 season. At all sites, experiments were established in the first ratoon cycle, and the plant cane (previous cycle) was harvested without burning the residues, leaving a straw layer (formed by dry leaves and tops) over the soil surface. Conventional tillage (plowing, disking, harrowing, and furrowing) and soil correction (application of lime and gypsum) were performed, on average, every 6 years at all sites. Site 1 was located in Piracicaba $\left(22^{\circ} 35^{\prime} \mathrm{S} ; 47^{\circ} 37^{\prime} \mathrm{W}\right)$, in a Typic Hapludox soil (Soil Survey Staff, 2014). Plant cane (cultivar SP89-1115, released by Copersucar) was mechanically green harvested in 
May 2009, at 433 DAP. Site 2 was located in Santa Cruz das Palmeiras $\left(21^{\circ} 47^{\prime} S ; 47^{\circ} 11^{\prime} \mathrm{W}\right.$ ), in a Typic Eutrustox soil (Soil Survey Staff, 2014). Plant cane (cultivar SP81-3250, released by Copersucar) was also mechanically green harvested in June 2009 (456 DAP). Further details related to soil characteristics and fertilizer and by-product management history for Sites 1 and 2 can be found in Mariano et al. (2015) and Vieira-Megda et al. (2015). Site 3 was located in Severínia $\left(20^{\circ} 46^{\prime} S ; 48^{\circ} 45^{\prime} \mathrm{W}\right)$, in a Typic Eutrustox (Soil Survey Staff, 2014). The cultivar planted was RB855453 (released by Ridesa), and the plant cane was harvested without prior burning in August 2012, at 442 DAP. As related to the genotypes, cultivar SP89-1115 is marketed as early ripening, average for yield potential, sucrose and fiber levels; cultivar SP81-3250 has a middle ripening, with high sugarcane yield potential, sucrose and fiber levels; and cultivar RB855453 is early ripening, but also with high yield potential and sucrose, and average fiber levels (Tasso Júnior, 2007; Ridesa, 2010).

\section{Soil Characterization and Experimental Setup}

Before the onset of the field trial, four composite soil samples (obtained by combining and mixing nine individual samples into a single sample per block) were taken at $20-\mathrm{cm}$ soil depth intervals until $100-\mathrm{cm}$ soil layer for soil physicochemical characterization. Soil $\mathrm{pH}$ was determined with $0.01 \mathrm{~mol} \mathrm{~L}^{-1}$ $\mathrm{CaCl}_{2}$ (ratio of 1:2.5 for soil and solution - w/v; van Raij et al., 2001). Soil organic C was determined by wet oxidation following the Walkley-Black procedure (Nelson and Sommers, 1996). Available $\mathrm{P}, \mathrm{K}$, calcium $(\mathrm{Ca})$, and magnesium $(\mathrm{Mg})$ were extracted by ion-exchange resins, and then quantified by colorimetric $(\mathrm{P})$, flame photometric $(\mathrm{K})$, and atomic absorption spectroscopic ( $\mathrm{Ca}$ and $\mathrm{Mg}$ ) methods (van Raij et al., 2001). Sulfur $\left(\mathrm{SO}_{4}{ }^{-2}\right.$ S) was extracted with $\mathrm{Ca}\left(\mathrm{H}_{2} \mathrm{PO}_{4}\right)_{2}$ solution and determined by turbidimetry, while exchangeable aluminum $(\mathrm{Al})$ was extracted with $\mathrm{KCl}$ solution and then determined by titration (van Raij et al., 2001). CEC at pH 7.0 was measured by summation of exchangeable cations ( $\mathrm{K}, \mathrm{Ca}$, and $\mathrm{Mg}$ ) and potential acidity $(\mathrm{H}+\mathrm{Al})$. Base saturation was calculated by dividing the summation of exchangeable cations by CEC, and then multiplied by 100 . Clay content was determined by the densimeter method (Gee and Bauder, 1986). Physicochemical soil properties are displayed in Table $\mathbf{1 .}$

The experimental design within each location was a randomized complete block with four (Sites 1 and 2) or five (Site 3) replications. At Site 1, treatments were fertilizer $\mathrm{N}$ sources [ammonium chloride, ammonium nitrate, calcium ammonium nitrate, organo-mineral fertilizer, urea, and control (no- $\mathrm{N}$ added)], applied at a rate of $100 \mathrm{~kg} \mathrm{~N} \mathrm{ha}^{-1}$. For Site 2 , in addition to the above-cited treatments applied at Site 1, ammonium sulfate $\left(100 \mathrm{~kg} \mathrm{~N} \mathrm{ha}^{-1}\right)$ was also used. At Site 1 , plots were fertilized with $75 \mathrm{~kg} \mathrm{~K} \mathrm{ha}^{-1}$, while $125 \mathrm{~kg} \mathrm{~K} \mathrm{ha}^{-1}$ and $15 \mathrm{~kg} \mathrm{P} \mathrm{ha}^{-1}$ were added at Site 2. The sources of $\mathrm{K}$ and $\mathrm{P}$ used at both sites were $\mathrm{KCl}$ and triple superphosphate, respectively. At both sites, fertilizers were manually applied over the straw layer, in a band at $20 \mathrm{~cm}$ away from the plant row.

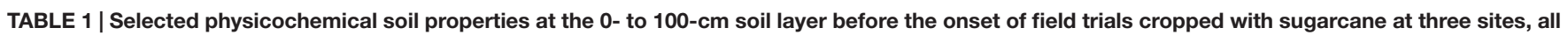
located in the Southeast region of Brazil.

\begin{tabular}{|c|c|c|c|c|c|c|c|c|c|c|c|}
\hline \multirow[t]{2}{*}{ Depth cm } & \multirow[t]{2}{*}{$\mathrm{pH}$} & \multirow[t]{2}{*}{$\operatorname{soc}^{a} \mathrm{~g} \mathrm{dm}^{-3}$} & $\mathbf{P}$ & $\mathrm{S}$ & K & $\mathrm{Ca}$ & $\mathbf{M g}$ & Al & $\mathrm{CEC}^{\mathrm{b}}$ & \multirow[t]{2}{*}{ BS $^{\mathbf{c}} \%$} & \multirow[t]{2}{*}{ Clay $\mathbf{g ~ k g} \mathbf{~}^{-1}$} \\
\hline & & & \multicolumn{2}{|c|}{$\mathrm{mg} \mathrm{dm}^{-3}$} & \multicolumn{5}{|c|}{$\mathrm{mmol}_{\mathrm{c}} \mathrm{dm}^{-3}$} & & \\
\hline \multicolumn{12}{|c|}{ Site 1 (Typic Hapludox soil ${ }^{\mathrm{d}}$ ) } \\
\hline $0-20$ & 4.6 & 23 & 29 & 33 & 4.3 & 13 & 6 & 5 & 95 & 24 & 510 \\
\hline $20-40$ & 4.6 & 19 & 29 & 50 & 4.6 & 29 & 12 & 5 & 126 & 36 & 530 \\
\hline $40-60$ & 4.3 & 19 & 5 & 95 & 4.9 & 13 & 8 & 11 & 124 & 21 & 500 \\
\hline $60-80$ & 4.1 & 14 & 2 & 107 & 5.5 & 8 & 6 & 13 & 117 & 17 & 580 \\
\hline 80-100 & 4.2 & 13 & 1 & 105 & 4.0 & 9 & 8 & 13 & 109 & 19 & 530 \\
\hline \multicolumn{12}{|c|}{ Site 2 (Typic Eutrustox soil ${ }^{\mathrm{d}}$ ) } \\
\hline $0-20$ & 5.5 & 17 & 8 & 27 & 0.7 & 49 & 13 & 0 & 91 & 69 & 630 \\
\hline $20-40$ & 4.8 & 13 & 16 & 92 & 0.3 & 33 & 10 & 2 & 85 & 51 & 630 \\
\hline $40-60$ & 4.6 & 10 & 2 & 116 & 0.2 & 19 & 8 & 4 & 69 & 39 & 640 \\
\hline 60-80 & 4.7 & 8 & 1 & 117 & 0.2 & 16 & 7 & 2 & 57 & 41 & 660 \\
\hline $80-100$ & 4.9 & 7 & 1 & 113 & 0.1 & 16 & 7 & 1 & 57 & 40 & 660 \\
\hline \multicolumn{12}{|c|}{ Site 3 (Typic Eutrustox soild) } \\
\hline 0-20 & 5.4 & 9 & 28 & 12 & 3.0 & 18 & 9 & 1 & 49 & 61 & 299 \\
\hline $20-40$ & 5.3 & 7 & 33 & 30 & 1.4 & 15 & 9 & 3 & 47 & 54 & 226 \\
\hline $40-60$ & 5.2 & 5 & 3 & 47 & 1.0 & 13 & 10 & 2 & 41 & 58 & 252 \\
\hline 60-80 & 5.2 & 5 & 2 & 50 & 0.8 & 14 & 10 & 1 & 39 & 64 & 298 \\
\hline $80-100$ & 5.2 & 4 & 2 & 49 & 0.8 & 12 & 11 & 1 & 33 & 71 & 275 \\
\hline
\end{tabular}

a Soil organic C.

${ }^{\mathrm{b}}$ Cation exchange capacity at $\mathrm{pH}$ 7.0.

cBase saturation.

dClassification refers to the Soil Taxonomy (Soil Survey Staff, 2014). 
For Site 3, treatments used were rates of HSS (35 g organic $\mathrm{C} \mathrm{kg}{ }^{-1} ; 115,230$, and $\left.460 \mathrm{~kg} \mathrm{HSS} \mathrm{ha}{ }^{-1}\right), \mathrm{N}(25,50$, and $100 \mathrm{~kg} \mathrm{~N} \mathrm{ha}^{-1}$ ) and specific interactions between both factors $\left(115 \mathrm{~kg} \mathrm{HSS} \mathrm{ha}^{-1}+25 \mathrm{~kg} \mathrm{~N} \mathrm{ha}^{-1}, 230 \mathrm{~kg} \mathrm{HSS} \mathrm{ha}{ }^{-1}+50 \mathrm{~kg}\right.$ $\mathrm{N} \mathrm{ha}^{-1}$, and $460 \mathrm{~kg} \mathrm{HSS} \mathrm{ha}^{-1}+100 \mathrm{~kg} \mathrm{~N} \mathrm{ha}^{-1}$ ). A control treatment (without addition of HSS and N) was also used. Humic substances were composed by fulvic and humic acids, both extracted and purified from peat, whereas $\mathrm{N}$ was applied as urea. The HSS and HSS $+\mathrm{N}$ treatments were applied directly to sugarcane leaves (foliar application), while $\mathrm{N}$ rates were banded added over the straw layer, at $20 \mathrm{~cm}$ away from the plant row. Treatments were added on September 2009, October 2009, and October 2012 at Sites 1, 2, and 3, respectively. Phosphorus and $\mathrm{K}$ recommendations were defined based on soil test methods (Table 1), whereas target yield concept was employed to predict fertilizer $\mathrm{N}$ requirements (Spironello et al., 1997). Biweekly precipitation and mean biweekly minimum and maximum air temperatures recorded at each site are displayed in Figure 1.

\section{Biomass and Plant Nutrient Content Measurements}

Plant measurements followed similar protocols at all sites, and a complete description can be found in Mariano et al. (2016). Briefly, plants were randomly collected from 3-m plant row $(\sim 30$ plants) in each experimental plot, and then separated into stalks, dry leaves, and tops at all four sampling times (comparable growth stages in all sites). In our study, tops refer to developing (green) leaves from the stalk breakpoint to the apical meristem. Sampling dates of plant biomass were performed at 139, 178, 235, and $330 \mathrm{DAH}$ for Site 1; at 133, 170, 227, and $331 \mathrm{DAH}$ for Site 2; and at 145, 198, 290, and $380 \mathrm{DAH}$ for Site 3. Fresh samples were weighed and then ground in a forage grinder. Subsamples of each plant component were oven dried at $65^{\circ} \mathrm{C}$ until achieving constant weight, then weighed for dry weight determination, and ground to pass through a $0.5-\mathrm{mm}$ sieve in a Wiley mill. Total $\mathrm{N}, \mathrm{P}$, and $\mathrm{K}$ concentration $\left(\mathrm{g} \mathrm{kg}^{-1}\right)$ in plant tissues were determined by steam distillation (Kjeldahl), gravimetry, and flame emission photometry, respectively (AOAC International, 2006). Total aboveground biomass accumulation (expressed in $\mathrm{Mg} \mathrm{ha}^{-1}$ ) was determined by the summation of all plant components collected in each sampling date. Total N, P, and $\mathrm{K}$ content $\left(\mathrm{kg} \mathrm{ha}^{-1}\right)$ in each plant component was calculated by multiplying each nutrient concentration by its respective biomass value (in dry weight). Final aboveground biomass and nutrient content were estimated based on the last sampling date performed at each site. Sugarcane yield $\left(\mathrm{Mg} \mathrm{ha}^{-1}\right)$ was estimated based on the fresh matter of stalks collected from 3-m plant row in the last sampling date.

\section{Biomass and Nutrient Partitioning}

Seasonal biomass partitioning in dry leaves, stalks, and tops of sugarcane collected along the ratoon cycle was fitted using a sigmoid equation for estimating the crop growth modeling (Mariano et al., 2016). The following equation (Eq. 1) was then

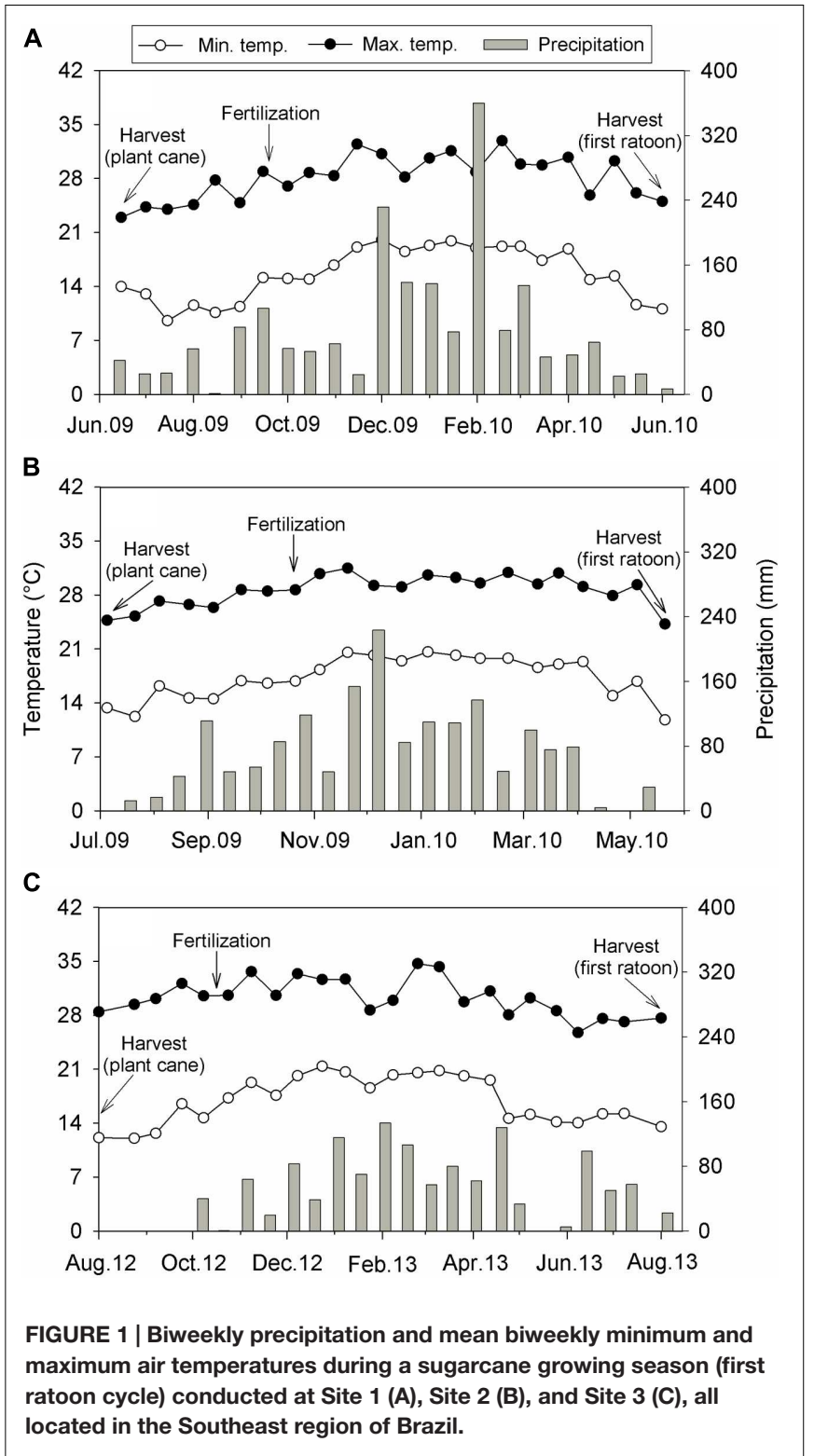

used to predict seasonal biomass within each plant component:

$$
Y=\frac{Y_{\max }}{\{1+\exp -[(\mathrm{DAH}-A) / B]\}}
$$

where $Y$ is the aboveground biomass $\left(\mathrm{Mg} \mathrm{ha}^{-1}\right) ; Y_{\max }$ is the maximum aboveground biomass $\left(\mathrm{Mg} \mathrm{ha}^{-1}\right)$ from harvest of the plant cane to harvest of the first ratoon; DAH is days after harvest of plant cane; $A$ and $B$ are constants.

Nutrient ( $N, P$, and $\mathrm{K}$ ) partitioning among each plant component along the ratoon cycle was fitted using a Gaussian equation (Eq. 2) as follows:

$$
Y=Y_{0}+A \times \exp \left\{-0.5 \times\left[\frac{D A H-B}{C}\right]^{2}\right\}
$$


where $Y$ is the aboveground nutrient $(\mathrm{N}, \mathrm{P}$, and $\mathrm{K})$ content $(\mathrm{kg}$ $\left.\mathrm{ha}^{-1}\right) ; Y_{0}$ is the intercept; DAH is days after harvest of plant cane; $A, B$, and $C$ are constants.

Thermal time was expressed as GDDs, which are calculated as accumulation of daily mean temperature values [(min. temperature + max. temperature)/2] minus a base temperature $\left(t_{b}\right)$, below which growth is assumed not to occur. In this study, $t_{b}$ was taken as $12^{\circ} \mathrm{C}$, an appropriate value for sugarcane, according to Allison et al. (2007). For terminology purposes, the term "aboveground" will be used throughout the text to refer to biomass and nutrient content in the following plant components: tops, dry leaves, and stalks.

\section{Harvest Index and Nutrient and Reciprocal Internal Efficiencies}

Harvest index was calculated as the stalks to the aboveground biomass ratio (all determined in dry weight basis) obtained in the last sampling date performed at each site. Similarly, nutrient $\mathrm{HI}$ for $\mathrm{N}, \mathrm{P}$, and $\mathrm{K}$ were determined as the nutrient content in the stalk as related to the total content in the aboveground plant fraction. NIE ( $\mathrm{kg}$ stalks $\mathrm{kg}^{-1}$ nutrient) was defined as the final sugarcane yield (converted from $\mathrm{Mg} \mathrm{ha}^{-1}$ to $\mathrm{kg} \mathrm{ha}^{-1}$ ) produced per $\mathrm{kg}$ of nutrient content $(\mathrm{N}, \mathrm{P}$, and $\mathrm{K})$ in aboveground biomass component according to Ciampitti and Vyn (2012). Therefore, the following equation (Eq. 3) was then used for the NIE calculation:

$$
\mathrm{NIE}=\left(\frac{\mathrm{SY}}{\mathrm{WNC}}\right)
$$

where NIE is nutrient internal efficiency; SY is the sugarcane yield $\left(\mathrm{kg} \mathrm{ha}^{-1}\right)$; and WNC is the whole-plant (aboveground) nutrient (N, P, and $\mathrm{K})$ content $\left(\mathrm{kg} \mathrm{ha}^{-1}\right)$.

In addition, the RIE ( $\mathrm{kg}$ nutrient $\mathrm{Mg}^{-1}$ stalk) was calculated according to Ciampitti and Vyn (2012), following the equation (Eq. 4):

$$
\mathrm{RIE}=\left(\frac{\mathrm{WNC}}{\mathrm{SY}}\right)
$$

where RIE is reciprocal internal efficiency; WNC is the wholeplant (aboveground) nutrient $(\mathrm{N}, \mathrm{P}$, and $\mathrm{K})$ content $\left(\mathrm{kg} \mathrm{ha}^{-1}\right)$; and $\mathrm{SY}$ is the sugarcane yield $\left(\mathrm{Mg} \mathrm{ha}^{-1}\right)$

\section{Statistical Analysis}

Although there were consistent differences among the three $\mathrm{N}$-response sites in terms of experimental conditions (e.g., nutrient rates applied, fertilizer sources, cultivars planted, etc.), this study performs a synthesis analysis to provide general information on nutrient content and partitioning, based on varying sugarcane yield levels, regardless of evaluated factors within each site. This approach was previously used by Setiyono et al. (2010) for corn. For all the parameters studied, descriptive statistics was determined through calculating mean, standard deviation, minimum, maximum, and $25-75 \%$ quartile. The equations used to predict seasonal biomass and nutrient partitioning (Eqs. 1 and 2) among plant components (stalks, dry leaves, and tops) were chosen based on their higher $R^{2}$ values than other functions tested. The relationship between the sugarcane yield versus the aboveground nutrient content and stalk nutrient content for $\mathrm{N}, \mathrm{P}$, and $\mathrm{K}$ was assessed through nonlinear regressions. The model adjusted was validated utilizing previously published studies (Shukla et al., 2009; Oliveira et al., 2010; Schultz et al., 2010) as to demonstrate the fitness and robustness of model calibration. The relationship between $\mathrm{N}$ content versus $\mathrm{P}$ and $\mathrm{K}$ content were also performed aimed to evaluate the N:P and N:K ratios within each plant component. All fitted regressions were determined using the SigmaPlot graphing software (version 11.0, 2008, Systat Software Inc., San Jose, CA, USA). The aboveground biomass accumulation, nutrient content, NIE, and RIE values obtained from all sites were stratified into diverse sugarcane yield ranges $(<80,80-100,100-120,120-140$, $140-160$, and $>160 \mathrm{Mg} \mathrm{ha}^{-1}$ ).

\section{RESULTS}

\section{Weather Conditions}

At the three sites, precipitation totals during the sugarcane growing season (equivalent to 12 months) were above the local average (Figure 1). At Site 1, precipitation reached 1,862 mm and was 1.5 -fold higher than the 81 -year average $(1,230 \mathrm{~mm}$; Figure 1A); precipitation at Site 2 totaled $1,691 \mathrm{~mm}$ and was 1.3 -fold greater than the 29-year average $(1,330 \mathrm{~mm}$; Figure $\mathbf{1 B})$; at Site 3, cumulative precipitation $(1,310 \mathrm{~mm})$ was slightly superior than the 17-year average $(1,266 \mathrm{~mm}$; Figure $1 \mathrm{C})$. The air temperatures recorded at each site (Figure 1) were similar to historical average. At Site 1, minimum air temperature varied from 9.5 to $20.0^{\circ} \mathrm{C}$, while maximum air temperature ranged from 24.2 to $32.9^{\circ} \mathrm{C}$. At Site 2 , minimum air temperature ranged from 11.8 to $20.6^{\circ} \mathrm{C}$, while maximum air temperature varied from 24.2 to $31.5^{\circ} \mathrm{C}$. Lastly, at Site 3 , minimum air temperature varied from 12.0 to $21.4^{\circ} \mathrm{C}$, and maximum air temperature ranged from 25.7 to $34.7^{\circ} \mathrm{C}$.

\section{Biomass, Nutrient Content, and Harvest Index}

A broad range in aboveground sugarcane biomass was recorded across all sites (Table 2). Sugarcane yield ranged from 67 to $211 \mathrm{Mg} \mathrm{ha}^{-1}$, averaging $125 \mathrm{Mg} \mathrm{ha}^{-1}$. Aboveground biomass ranged from 16 to $106 \mathrm{Mg} \mathrm{ha}^{-1}$, averaging $57 \mathrm{Mg} \mathrm{ha}^{-1}$. Stalk biomass ranged from 9 to $66 \mathrm{Mg} \mathrm{ha}^{-1}$, averaging $37 \mathrm{Mg} \mathrm{ha}^{-1}$, while tops mass ranged from 2 to $30 \mathrm{Mg} \mathrm{ha}^{-1}$ and averaged $11 \mathrm{Mg}$ $\mathrm{ha}^{-1}$. Dry leaves biomass ranged from 4 to $20 \mathrm{Mg} \mathrm{ha}^{-1}$, with an average of $9 \mathrm{Mg} \mathrm{ha}^{-1}$. Nutrient content within each plant component also had a broad variation (Table 2). The content of $\mathrm{N}, \mathrm{P}$, and $\mathrm{K}$ in the stalks ranged from 32 to $168 \mathrm{~kg} \mathrm{ha}^{-1}$, from 5 to $57 \mathrm{~kg} \mathrm{ha}^{-1}$, and from 26 to $713 \mathrm{~kg} \mathrm{ha}^{-1}$, respectively. The content of $\mathrm{N}, \mathrm{P}$, and $\mathrm{K}$ in the dry leaves ranged from 19 to $77 \mathrm{~kg} \mathrm{ha}^{-1}, 0.6$ to $4.9 \mathrm{~kg} \mathrm{ha}^{-1}$, and 2 to $96 \mathrm{~kg} \mathrm{ha}^{-1}$, respectively. Lastly, the content of $\mathrm{N}, \mathrm{P}$, and $\mathrm{K}$ in the tops ranged from 17 to $225 \mathrm{~kg} \mathrm{ha}^{-1}, 1$ to $26 \mathrm{~kg} \mathrm{ha}^{-1}$, and 75 to $396 \mathrm{~kg} \mathrm{ha}^{-1}$, respectively. As related to the aboveground plant fractions (dry leaves + tops + stalk), N content ranged from 86 to $425 \mathrm{~kg} \mathrm{~N}$ $\mathrm{ha}^{-1}$, averaging $197 \mathrm{~kg} \mathrm{~N} \mathrm{ha}^{-1}$, while $\mathrm{P}$ content ranged from 10 to $79 \mathrm{~kg} \mathrm{P} \mathrm{ha}^{-1}$, averaging $32 \mathrm{~kg} \mathrm{P} \mathrm{ha}^{-1}$ (Table 2). Aboveground 
TABLE 2 | Descriptive statistics related to sugarcane yield, aboveground biomass and its components (stalks, dry leaves, and tops), content of nitrogen $(\mathrm{N})$, phosphorus $(\mathrm{P})$, and potassium $(\mathrm{K})$ allocated in each plant component, $\mathrm{HI}$ and $\mathrm{HI}$ of $\mathrm{N}$, $\mathrm{P}$, and $\mathrm{K}$ for sugarcane (first ratoon cycle) across three sites located in the Southeast region of Brazil $(n=102)$.

\begin{tabular}{|c|c|c|c|c|c|c|c|c|}
\hline Parameter & Unit & Mean & $S D^{\mathrm{a}}$ & Minimum & $25 \% Q^{b}$ & Median & $75 \% Q^{c}$ & Maximum \\
\hline Sugarcane yield & $\mathrm{Mg} \mathrm{ha}^{-1}$ & 125 & 42 & 67 & 84 & 119 & 164 & 211 \\
\hline Aboveground biomass & $\mathrm{Mg} \mathrm{ha}^{-1}$ & 57 & 28 & 16 & 29 & 46 & 84 & 106 \\
\hline Stalk biomass & $\mathrm{Mg} \mathrm{ha}^{-1}$ & 37 & 18 & 9 & 20 & 31 & 54 & 66 \\
\hline Dry leaves biomass & $\mathrm{Mg} \mathrm{ha}^{-1}$ & 9 & 3 & 4 & 6 & 8 & 11 & 20 \\
\hline Tops biomass & $\mathrm{Mg} \mathrm{ha}^{-1}$ & 11 & 7 & 2 & 4 & 8 & 18 & 30 \\
\hline Aboveground $\mathrm{N}$ content & $\mathrm{kg} \mathrm{ha}^{-1}$ & 197 & 73 & 86 & 135 & 175 & 254 & 425 \\
\hline Aboveground P content & $\mathrm{kg} \mathrm{ha}^{-1}$ & 32 & 18 & 10 & 14 & 27 & 45 & 79 \\
\hline Aboveground $\mathrm{K}$ content & $\mathrm{kg} \mathrm{ha}^{-1}$ & 469 & 169 & 159 & 366 & 502 & 578 & 866 \\
\hline Stalk N content & $\mathrm{kg} \mathrm{ha}^{-1}$ & 90 & 31 & 32 & 64 & 88 & 112 & 168 \\
\hline Stalk P content & $\mathrm{kg} \mathrm{ha}^{-1}$ & 19 & 12 & 5 & 8 & 16 & 26 & 57 \\
\hline Stalk K content & $\mathrm{kg} \mathrm{ha}^{-1}$ & 266 & 153 & 26 & 202 & 275 & 346 & 713 \\
\hline Dry leaves $\mathrm{N}$ content & $\mathrm{kg} \mathrm{ha}^{-1}$ & 34 & 11 & 19 & 27 & 33 & 39 & 77 \\
\hline Dry leaves P content & $\mathrm{kg} \mathrm{ha}^{-1}$ & 2.0 & 1.0 & 0.6 & 1.2 & 1.7 & 2.5 & 4.9 \\
\hline Dry leaves K content & $\mathrm{kg} \mathrm{ha}^{-1}$ & 26 & 18 & 2 & 13 & 19 & 36 & 96 \\
\hline Tops N content & $\mathrm{kg} \mathrm{ha}^{-1}$ & 74 & 45 & 17 & 33 & 54 & 110 & 225 \\
\hline Tops P content & $\mathrm{kg} \mathrm{ha}^{-1}$ & 11 & 7 & 1 & 5 & 8 & 17 & 26 \\
\hline Tops K content & $\mathrm{kg} \mathrm{ha}^{-1}$ & 177 & 58 & 75 & 133 & 171 & 209 & 396 \\
\hline Harvest index ${ }^{d}$ & - & 0.65 & 0.04 & 0.55 & 0.64 & 0.66 & 0.68 & 0.73 \\
\hline $\mathrm{N}$ harvest index ${ }^{\mathrm{e}}$ & - & 0.46 & 0.06 & 0.31 & 0.41 & 0.46 & 0.50 & 0.64 \\
\hline$P$ harvest index ${ }^{e}$ & - & 0.57 & 0.08 & 0.38 & 0.51 & 0.57 & 0.62 & 0.81 \\
\hline $\mathrm{K}$ harvest index ${ }^{\mathrm{e}}$ & - & 0.52 & 0.19 & 0.12 & 0.45 & 0.53 & 0.65 & 0.82 \\
\hline
\end{tabular}

a Standard deviation.

${ }^{\mathrm{b}}$ First quartile.

cThird quartile.

dCalculated as the stalks to the aboveground biomass ratio.

${ }^{e} \mathrm{Calculated}$ as the nutrient content in the stalk as related to the total content in the aboveground plant fraction.

$\mathrm{K}$ content followed a similar trend related to the $\mathrm{N}$ content (Table 2), with values ranging between 159 and $866 \mathrm{~kg} \mathrm{~K} \mathrm{ha}^{-1}$, averaging $469 \mathrm{~kg} \mathrm{~K} \mathrm{ha}^{-1}$. The biomass $\mathrm{HI}$ had a narrow range, varying from 0.55 to 0.73 across all evaluated sites (Table 2). In contrast, nutrient $\mathrm{HI}$ showed a broad range, varying from 0.31 to 0.64 for $\mathrm{N}, 0.38$ to 0.81 for $\mathrm{P}$, and 0.12 to 0.82 for $\mathrm{K}$. Detailed results about biomass accumulation, nutrient content, and HI for each specific treatment within each site can be found in Supplementary Table 1.

\section{Biomass and Nutrient Partitioning}

Sugarcane biomass accumulation throughout the ratoon cycles was characterized by a sigmoid pattern (Figure 2A). The nonlinear growth regression equation included data from all sites, and three distinct growth phases were identified, as follows: (1) Phase I (lag phase): from $\sim 0$ to $135 \mathrm{DAH}\left(0\right.$ to $1450^{\circ} \mathrm{C}$ GDDs), this period is marked by a slow plant growth, accumulating $\sim 10 \%$ of the final aboveground biomass relative to harvest; (2) Phase II (exponential-linear phase): from $\sim 135$ to $270 \mathrm{DAH}$ ( 1450 to $2800^{\circ} \mathrm{C}$ GDDs), this period was characterized by a rapid growth that produced $\sim 65 \%$ of the final aboveground biomass relative to harvest; and (3) Phase III (stationary phase): from $\sim 270$ to $370 \mathrm{DAH}$ (2800 to $4000^{\circ} \mathrm{C}$ GDDs), this period exhibited a declined growth, representing $\sim 25 \%$ of the final aboveground biomass at harvest. As related to the nutrient uptake, 50\% of the total N, P, and K content occurred at 212 (2259 GDDs), 209 (2292 GDDs), and 214 DAH (2314 GDDs), respectively, while $50 \%$ of biomass accumulation was detected at $250 \mathrm{DAH}(2700$ GDDs; Figures 2B-D). Thus, there was an asynchrony (delay) of $\sim 38$ days, on average, between the date when $50 \%$ of the total aboveground biomass occurred in comparison when $50 \%$ of total nutrient had accumulated.

In the partitioning process, Phase I was marked by the biomass allocation exclusively in the tops, as the occurrence of dried leaves and stalk was not visible at that growth stage (Figure 2A). However, an opposite trend was observed for Phases II and III, where most of the biomass was allocated in the stalk, followed by tops and dry leaves. The fraction of biomass allocated in the stalk was $\sim 65 \%$ of the total, which are similar toother studies, ranging from 60 to $80 \%$ (Coale et al., 1993; Inman-Bamber et al., 2002; Shukla et al., 2009; Trivelin et al., 2013). The nutrient partitioning followed the same trend as verified for biomass accumulation (Figures 2B-D), although a higher proportion of N, P, and K were allocated in the tops than dry leaves in the Phases II and III.

\section{Yield-to-Nutrient Content Relationship Sugarcane Yield}

Sugarcane yield was positively related to the aboveground and stalk nutrient content, with a less than proportional change for nutrient content under high-yielding stalk observations 

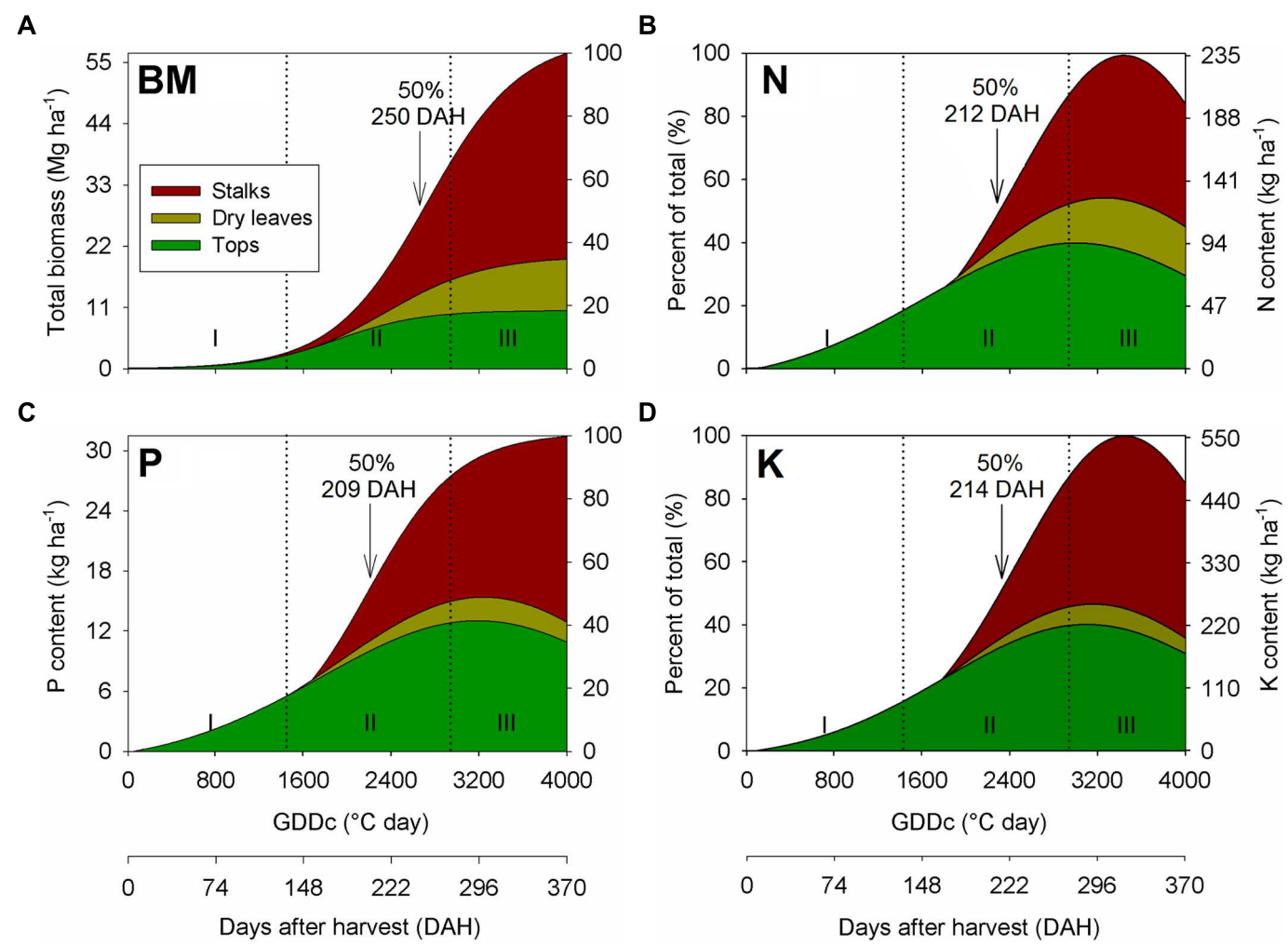

FIGURE 2 | Seasonal aboveground biomass (BM; A), nitrogen (N; B), phosphorus (P; C), and potassium (K; D) accumulation and partitioning in stalks, dry leaves, and tops of sugarcane during a first ratoon growing season, in overall for all three site-years located in the Southeast region of Brazil.

Arrows indicate when sugarcane BM and nutrient accumulation achieved $50 \%$ relative to its final content at harvest time.

(Figure 3). Both $\mathrm{N}$ and $\mathrm{P}$ showed a narrow relationship with sugarcane yield $\left(R^{2} \geq 0.66\right)$, but $\mathrm{K}$ presented wider variability, thus resulting in non-significant relationships $\left(R^{2} \leq 0.13\right.$; Figures 3C,F). For the yield-to-K relationship, Site 1 showed a range varying from 356 to $866 \mathrm{~kg} \mathrm{~K} \mathrm{ha}^{-1}$ for a comparable yield level (Figure $3 \mathrm{C}$ ), whereas for Site $2, \mathrm{~K}$ and $\mathrm{P}$ may have limited sugarcane yield with similar stalk $\mathrm{K}\left(70 \mathrm{~kg} \mathrm{ha}^{-1}\right)$ and $\mathrm{P}$ $\left(9 \mathrm{~kg} \mathrm{ha}^{-1}\right.$ ) content, with yield ranging from 65 to $120 \mathrm{Mg} \mathrm{ha}^{-1}$ (Figures 3E,F).

\section{N:P and N:K Stoichiometry in Sugarcane Plant Components}

Evaluation of nutrient stoichiometry can provide an overall status of nutrient balance at a specific growth stage. Following this rationale, $\mathrm{N}: \mathrm{P}$ ratio was established for all plant components (stalk, dry leaves, and tops) at harvest time (Figure 4). Bubble graphs portrayed N:P content association as relative to sugarcane yield (represented by bubble sizes; Figure 4). At the aboveground biomass level, N:P ratio presented an overall balance close to 6:1 units (Figure 4A), although the N:P ratio changed relative to the plant fraction: 18 units for dry leaves (Figure 4B), 6 unit for tops (Figure 4C), and 4 units for the stalk organ (Figure 4D). The tops followed a similar N:P ratio as documented for the aboveground plant, which exemplify the critical role of this organ for $\mathrm{C}$ fixation and growth/yield, with a variation from
3:1 to 11:1 (<threefold; Figure 4C). High-yielding sugarcane observations presented a more balanced $\mathrm{N}: \mathrm{P}$ ratio (6:1 units). For example, sugarcane yield of $120 \mathrm{Mg} \mathrm{ha}^{-1}$ resulted in $70 \mathrm{~kg} \mathrm{~N}$ $\mathrm{ha}^{-1}$ and $12 \mathrm{~kg} \mathrm{P} \mathrm{ha}^{-1}$ (N:P of six units) for the tops component (Figure 4C).

The stoichiometric evaluation was also calculated for $\mathrm{N}$ and $\mathrm{K}$, but more variation was present than the N:P ratio. The overall $\mathrm{N}: \mathrm{K}$ ratio was of $0.5: 1$ units, ranging from $0.1: 1$ to $1.2: 1$ ( $>10$-fold variation; Supplementary Figure S1). Accordingly to the N:P ratio, the $\mathrm{N}: \mathrm{K}$ stoichiometry presented a similar variation range in the tops component relative to the aboveground biomass. Detailed information about nutrient ratios (N:P and $\mathrm{N}: \mathrm{K})$ for treatments used at each site can be found in Supplementary Table 1.

\section{Efficiency Indexes on Diverse Sugarcane Yield Ranges}

As expected, both biomass and nutrient content followed the yield pattern (Table 3). In low-yield levels, marked by yields $<80 \mathrm{Mg} \mathrm{ha}^{-1}$, the aboveground biomass was of $26 \mathrm{Mg}$ $\mathrm{ha}^{-1}$, whereas aboveground nutrient content was of 117,16 , and $233 \mathrm{~kg} \mathrm{ha}^{-1}$ of $\mathrm{N}, \mathrm{P}$, and $\mathrm{K}$, respectively. However, under highyield levels (>160 $\mathrm{Mg} \mathrm{ha}^{-1}$ ), the biomass was of $89 \mathrm{Mg} \mathrm{ha}^{-1}$, while nutrient content was of 279,50 , and $560 \mathrm{~kg} \mathrm{ha}^{-1}$ of N, P, and $\mathrm{K}$, respectively. 

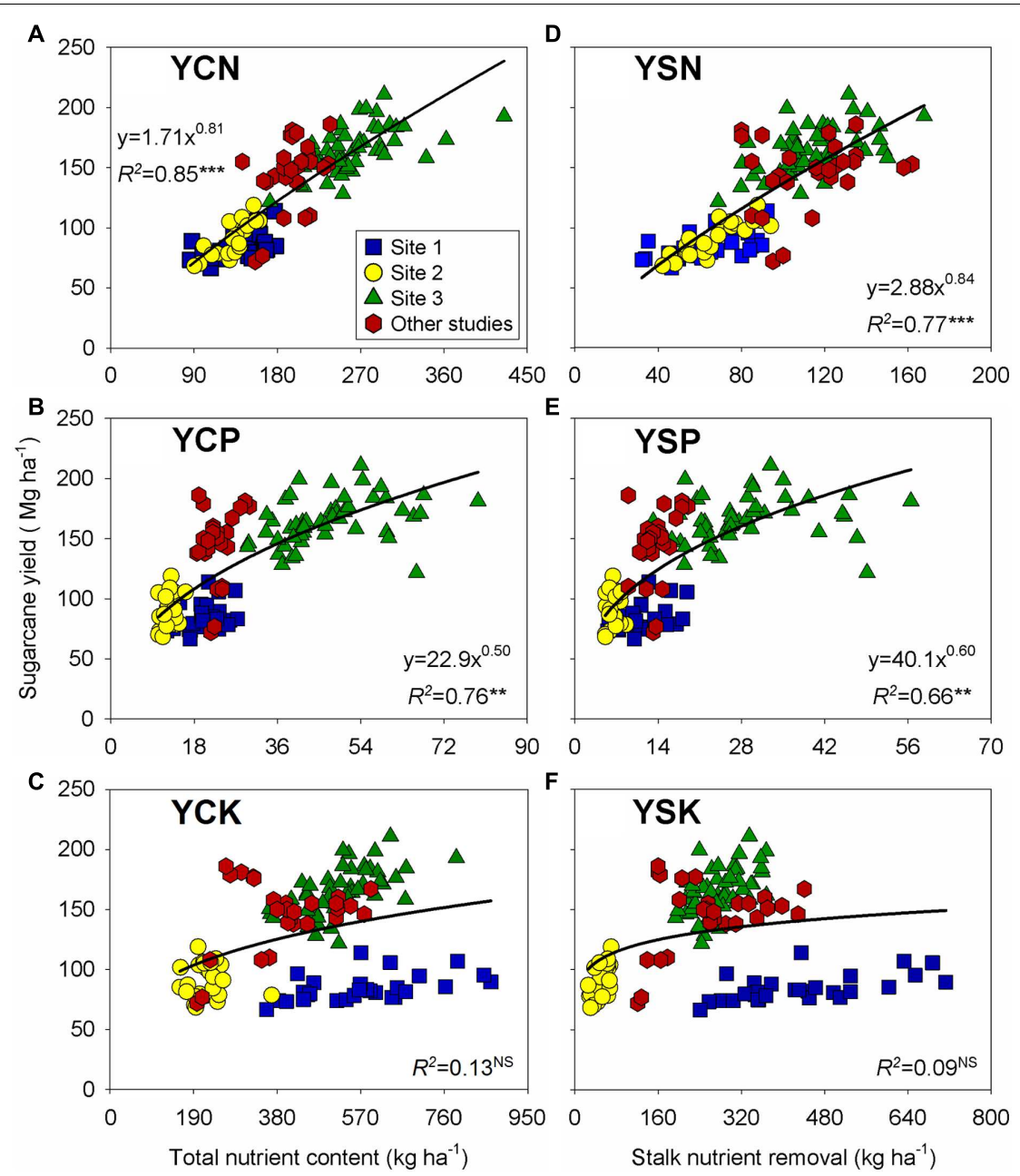

FIGURE 3 | Relationships between sugarcane yield versus aboveground nutrient content for $N(A), P(B)$, and K (C); and versus stalk nutrient content (nutrient removal) for $\mathbf{N}(\mathbf{D}), \mathbf{P}$ (E), and $\mathbf{K}(\mathbf{F})$. Each data point represents an individual field plot at sugarcane harvest of a first ratoon growing season for three site-years $(n=102)$. Red symbols were gathered from previously published documents (Shukla et al., 2009; Oliveira et al., 2010; Schultz et al., 2010; $n=27$ ). ***, **, and NS: $p \leq 0.001, p \leq 0.01$, and non-significant $(p>0.05)$, respectively.

Sugarcane yield influenced all internal nutrient efficiencies for $\mathrm{N}$, P, and K (Table 3). Maximum NIEs [713 $\mathrm{kg}$ stalk $\mathrm{kg}^{-1} \mathrm{~N}$, $5962 \mathrm{~kg}$ stalk kg $^{-1} \mathrm{P}$, and $478 \mathrm{~kg}$ stalk $\mathrm{kg}^{-1} \mathrm{~K}$ ] occurred at lowest sugarcane yield ( $<80 \mathrm{Mg} \mathrm{ha}^{-1}$ ), while minimum NIEs [623 kg stalk $\mathrm{kg}^{-1} \mathrm{~N}, 3649 \mathrm{~kg}$ stalk $\mathrm{kg}^{-1} \mathrm{P}$, and $320 \mathrm{~kg}$ stalk $\left.\mathrm{kg}^{-1} \mathrm{~K}\right]$ occurred at highest sugarcane yield ( $>160 \mathrm{Mg} \mathrm{ha}^{-1}$ ). Reciprocal internal efficiencies were estimated for low and high sugarcane yields (from 80 to $160 \mathrm{Mg} \mathrm{ha}^{-1}$ ), requiring $1.3-1.6 \mathrm{~kg} \mathrm{~N}, 0.21-$ $0.28 \mathrm{~kg} \mathrm{P}$, and 2.4-3.2 kg K per Mg of stalk produced, respectively (Table 3). Oliveira (2011) reported a similar trend for RIE, with values of $1.5,0.21$, and $3.1 \mathrm{~kg}$ of $\mathrm{N}, \mathrm{P}$, and $\mathrm{K}$, respectively.

\section{DISCUSSION}

The high yielding observations reported in this study were greater than previous sugarcane yield values documented by others researchers in Brazil (Gava et al., 2005; Prado and
Pancelli, 2008; Oliveira, 2011; Amaral and Molin, 2013; Fortes et al., 2013; Otto et al., 2013; Rossato et al., 2013), Australia (Thorburn et al., 2011) and United States (Coale et al., 1993; McCray et al., 2014). In this study, Site 3 represents a highyielding and productive sugarcane environment, likely explained by the combination of high soil fertility and utilization of best management practices, such as variable rate fertilizer spreader and controlled traffic through GPS guided maps. It is recognized that sugarcane yield depends on the complex interaction among genotypes, environment (soil and weather), and management practices (Thorburn et al., 2011). Several factors can contribute to the scatter and non-linear differences in yield that affect its relationship between nutrients (Setiyono et al., 2010). In this study, weather conditions, such as air temperature and precipitation, were similar for all sites (Figure 1), with a main difference related to the soil type and fertility status (Table $\mathbf{1}$ ). For example, in Site 1, average $\mathrm{pH}$ (4.3 units) and base saturation $(23 \%)$ were relatively low at all evaluated soil-depth intervals, 


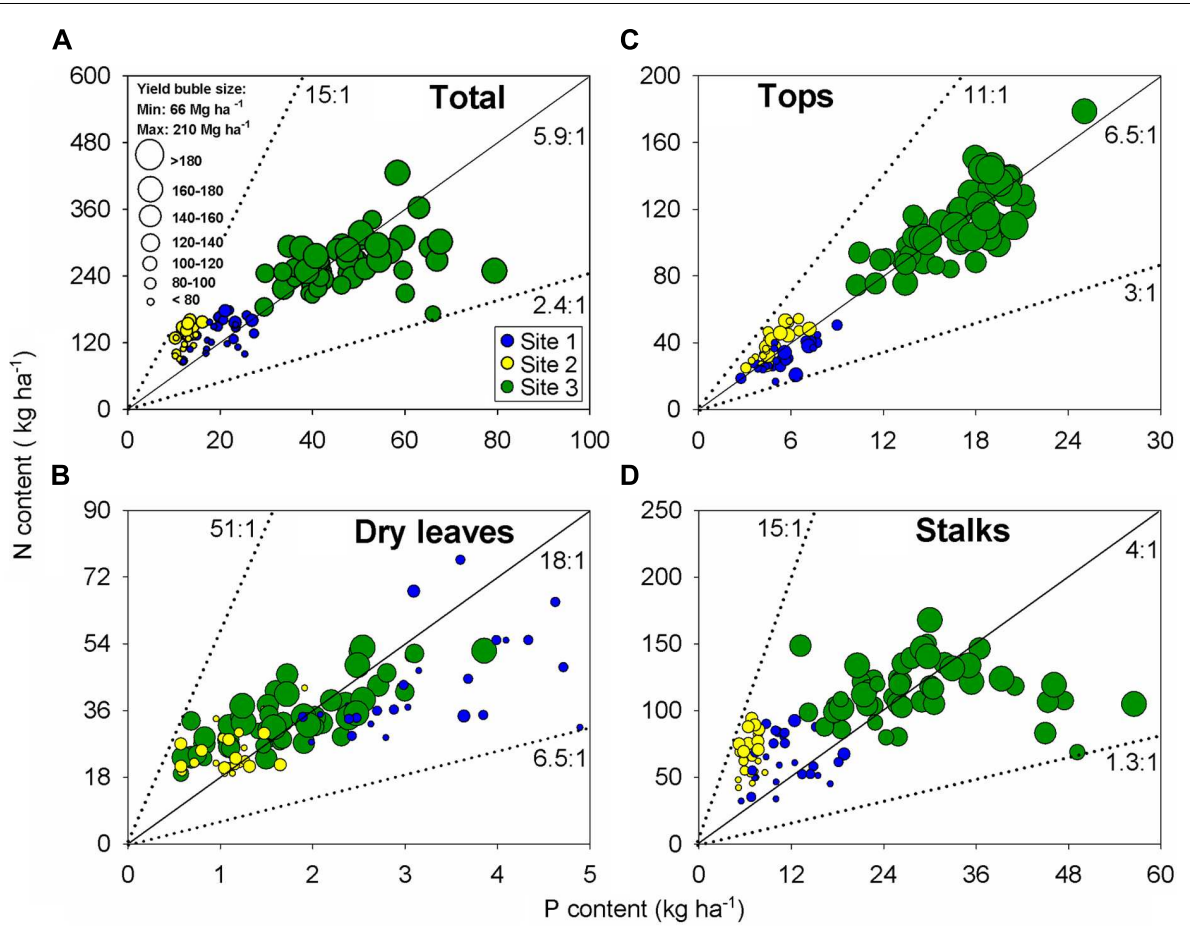

FIGURE 4 | Relationships between N versus P content for all plant components: aboveground biomass (A), dry leaves (B), tops (C), and stalks (D). Each data point represents an individual field plot at sugarcane harvest of a first ratoon growing season for three site-years $(n=102)$. Dotted lines show boundary ratios for each component between $\mathrm{N}$ versus $\mathrm{P}$, and black line shows the average value.

accompanied with high $\mathrm{Al}$ content $\left(9.5 \mathrm{mmol}_{\mathrm{c}} \mathrm{dm}^{-3}\right)$ when compared to Site 3 (Table 1). For Site 2, the main limiting factors were $\mathrm{K}\left(0.3 \mathrm{mmol}_{\mathrm{c}} \mathrm{dm}^{-3}\right)$ and $\mathrm{P}\left(5.6 \mathrm{mg} \mathrm{dm}^{-3}\right)$ levels. In summary, Sites 1 and 2 presented initial soil conditions that could constraint and severely affect sugarcane yield potential relative to Site 3. In agreement, Dias et al. (1999), documented a strong correlation between sugarcane yields and chemical properties (e.g., CEC, base saturation, exchangeable $\mathrm{Ca}, \mathrm{Mg}$, and $\mathrm{Al}$, potential acidity, etc.) of subsurface horizons $(25-150 \mathrm{~cm})$ of six weathered soils. Treatment effect was more pronounced on Sites 1 and 2 than Site 3 (Supplementary Table 1), which was likely due to variations in soil chemical properties as described above.

Although the aboveground $\mathrm{N}$ content presented a broad variation, the overall absolute value was similar with others studies (Wood et al., 1996; Oliveira et al., 2010; Franco et al., 2011). Wood et al. (1996) documented total $\mathrm{N}$ content values ranging from 212 to $254 \mathrm{~kg} \mathrm{~N} \mathrm{ha}^{-1}$ for several sugarcane cultivars. Franco et al. (2011) found total $\mathrm{N}$ content values ranging from 95 to $154 \mathrm{~kg} \mathrm{ha}^{-1}$, while sugarcane yield ranged between 77 and $122 \mathrm{Mg} \mathrm{ha}^{-1}$ at the same study sites (Franco et al., 2015). Oliveira et al. (2010) reported that $\mathrm{N}$ content ranged between 94 and $260 \mathrm{~kg} \mathrm{~N}^{-1}$, while sugarcane yield ranged from 120 to $232 \mathrm{Mg} \mathrm{ha}^{-1}$ for 11 sugarcane cultivars under irrigation in northeastern Brazil. Differences in $\mathrm{N}$ content could be explained by the higher yields obtained in the present study (average of $125 \mathrm{Mg} \mathrm{ha}^{-1}$ ). Other $\mathrm{N}$ sources rather than mineral fertilizer (e.g., soil $\mathrm{N}$ mineralization, atmospheric deposition, and biological $\mathrm{N}$ fixation by endophytic bacteria) can provide different amount of $\mathrm{N}$ for sugarcane crop (Urquiaga et al., 2012; Mariano et al., 2013; Otto et al., 2013; Vieira-Megda et al., 2015). For this study, aboveground $\mathrm{P}$ content presented a similar range from 21 to $39 \mathrm{~kg} \mathrm{P} \mathrm{ha}^{-1}$ as reported by several researchers (Rakkiyappan et al., 2007; Shukla et al., 2009; Oliveira et al., 2010). As related to the K content, Coale et al. (1993) and Shukla et al. (2009) reported lower values for K content removal by crop harvest of 340 and $228 \mathrm{~kg} \mathrm{~K} \mathrm{ha}^{-1}$ with sugarcane yield of 96 and $80 \mathrm{Mg} \mathrm{ha}^{-1}$, respectively. For our study, high $\mathrm{K}$ content might have been influenced by the soil nutrient content presented at Site 1 , where soil $\mathrm{K}$ level was $\geq 4.0 \mathrm{mmol}_{\mathrm{c}} \mathrm{dm}^{-3}$ throughout the soil profile (Table 1). This experimental site has a long history of annual applications of vinasse and press mud. As vinasse has a high $\mathrm{K}$ content, amendment of this by-product might have gradually enriched soil $\mathrm{K}$ content (Resende et al., 2006). Thus, scientific literature is available portraying the critical role of sustaining an adequate $\mathrm{K}$ content for increasing sugarcane yields (Shukla et al., 2009).

Under optimal water, solar radiation, and temperature conditions, nutrient supply is the primary limiting factor affecting the process of biomass accumulation (Donaldson et al., 2008; van Heerden et al., 2010). For this study, a similar biomass accumulation pattern was previously described by others authors for plant cane and ratoon cycles for a broad range of cultivars, soil characteristics, and environmental conditions (Machado et al., 1982; Coale et al., 1993; Inman-Bamber et al., 2002; Gava et al., 2005). Phase I comprised the growth and 
TABLE 3 | Sugarcane yield, aboveground biomass accumulation (ABA), aboveground nutrient content (ANC), nutrient internal efficiencies (NIE), and reciprocal internal efficiencies (RIE) of N, P, and K for diverse sugarcane yield ranges across three sites located in the Southeast region of Brazil.

\begin{tabular}{|c|c|c|c|c|c|c|c|c|c|c|}
\hline \multirow[t]{2}{*}{ Yield Mg ha-1 } & \multirow[t]{2}{*}{ ABA Mg ha $a^{-1}$} & \multicolumn{3}{|c|}{ ANC kg ha-1 } & \multicolumn{3}{|c|}{$\mathrm{NIE}^{\mathrm{a}} \mathbf{k g}$ stalks $\mathbf{k g}^{-1}$ nutrient } & \multicolumn{3}{|c|}{ RIE $^{\mathrm{b}}$ kg nutrient $\mathrm{Mg}^{-1}$ stalk } \\
\hline & & $\mathbf{N}$ & $\mathbf{P}$ & K & $\mathbf{N}$ & $\mathbf{P}$ & K & $\mathbf{N}$ & $\mathbf{P}$ & $\mathbf{K}$ \\
\hline$<80$ & 26 & 117 & 16 & $233^{\mathrm{C}}(381)$ & 713 & 5962 & $478^{C}(233)$ & 1.3 & 0.21 & $2.4^{\mathrm{C}}(5.1)$ \\
\hline $80-100$ & 29 & 141 & 19 & 244 (485) & 697 & 5480 & $467(248)$ & 1.3 & 0.20 & $2.4(5.4)$ \\
\hline $100-120$ & 38 & 149 & 25 & $281(333)$ & 683 & 5266 & $439(403)$ & 1.4 & 0.23 & $2.5(3.2)$ \\
\hline $120-140$ & 60 & 198 & 33 & 335 (335) & 664 & 4761 & 329 (329) & 1.5 & 0.26 & $2.6(2.6)$ \\
\hline $140-160$ & 77 & 245 & 42 & $486(486)$ & 629 & 3750 & 319 (319) & 1.6 & 0.27 & $3.2(3.2)$ \\
\hline$>160$ & 89 & 279 & 50 & $560(560)$ & 623 & 3649 & 320 (320) & 1.6 & 0.28 & $3.2(3.2)$ \\
\hline
\end{tabular}

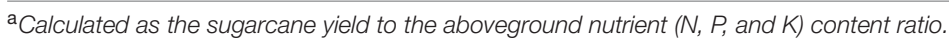

${ }^{\mathrm{b}} \mathrm{Calculated}$ as aboveground nutrient ( $N, P$, and $\left.K\right)$ content to the sugarcane yield ratio.

${ }^{\mathrm{c}}$ Data from Site 1 were removed from the calculation due to the high $\mathrm{K}$ content verified in the plant components, while values in parentheses included all sites.

phenology of sugarcane from emergence to $50 \%$ leaf production (half of tops already formed; Figure 2). The slow growth is related to the slow tillering and leaf production during plant establishment (Bell and Garside, 2005; Allison et al., 2007). Phase II is characterized by an exponential-linear biomass accumulation, consisting in leaf canopy and stalks production. After canopy establishment, the sugarcane is high efficient in converting intercepted light into biomass (Rae et al., 2005; Allison et al., 2007). The last stage (Phase III) is marked by the crop ripening and consequent sucrose accumulation in the stalk organ. Low air temperatures, reduced precipitation, and low-light photoperiod are important factors for the sugarcane ripening (Inman-Bamber et al., 2002; Cardozo and Sentelhas, 2013). At all sites, nutrients were accumulated in a linear fashion approach during Phase II as related to the potential yield production in each environment. However, in mid-point of Phase III, there was a decrease in the $\mathrm{N}$ and $\mathrm{K}$ content for all components (stalks, tops, and dry leaves; Figure 2). Thus, we have two hypothesis for this nutrient changes close to physiological maturity (ripening): (1) nutrient remobilization from aboveground plant components to belowground organs, such as roots and rhizomes (Andersson et al., 2005; Lim et al., 2007); and (2) specific to $\mathrm{N}$ allocated in the tops and dry leaves, foliar emissions of ammonia via stomata can occur during the leaf senescence, reducing the $\mathrm{N}$ content in plant tissues (Britto and Kronzucker, 2002; Epstein and Bloom, 2005).

Dissection of plant components for studying biomass HI is critical for understanding efficiency and potential yield for sugarcane. Inman-Bamber et al. (2002) suggested that the biomass HI (stalks to the aboveground biomass ratio) might be variable due to the amounts of straw (dry leaves and tops) recovered during the sampling procedure of sugarcane age field. In this investigation, dry leaves and tops comprised sugarcane straw, whereas tops are the plant component that accumulates the greatest amounts of nutrients $(\sim 60 \% \mathrm{~N}, \sim 75 \% \mathrm{P}$, and $\sim 80 \% \mathrm{~K}$ ) as compared to dry leaves (Figure 2; Table 2). According to Trivelin et al. (2013), since dry leaves have low nutrient content, tops is a critical plant component that should remain as a crop residue to sustain long-term soil fertility. However, excessive stalk lodging in sugarcane fields (caused by high yields and winds) may lead to low return of the tops as straw component, since the whole plant is processed by the harvester rather than prior cutting of tops and its direct deposition on the ground. In this scenario, contribution of nutrients released from the straw for sugarcane nutrition can be less significant. From the nutrient HI results (Table 2), the $\mathrm{N}$ replacement concept (Thorburn et al., 2011), based on the fertilizer $\mathrm{N}$ application to replace the $\mathrm{N}$ removed from the system (stalk harvested), is a promising way to recommend fertilizer needs for sugarcane not only for $\mathrm{N}$, but also for $\mathrm{P}$ and $\mathrm{K}$. This approach may deliver superior environmental outcome without reducing sugarcane yield. However, as $\mathrm{HI}$ was not constant for any nutrient (ranging from 0.12 to 0.82 , considering $\mathrm{N}, \mathrm{P}$, and $\mathrm{K}$ ), future research on robust models for optimizing the replacement concept is needed (Setiyono et al., 2010). Low nutrient HIs for sugarcane should be considered as a better plant trait, in opposite to the biomass partitioning (HI), since more nutrients are retained in nonharvested plant components (straw) and then released to the soil through leaching (for $\mathrm{K}$ ) and mineralization (for $\mathrm{N}$ and $\mathrm{P}$ ).

Nutrient-yield relationships for $\mathrm{N}$ and $\mathrm{P}$ presented a narrowed variation for both stalks and aboveground plant relative to $\mathrm{K}$ variation on those plant organs (Figure 3). Potassium is the most important nutrient in the osmoregulation process, which is important for cell extension and stomata movement (Shukla et al., 2009; Kingston, 2014). We can speculate that the tops (functional leaves) have kept more balanced nutrient ratios for metabolic functions (Groot et al., 2003; Güsewell, 2004). Nutrient surplus (e.g., Site 1, with high K content in the soil) can be storage in other component (stalk organ), presenting a low $\mathrm{N}: \mathrm{K}$ ratio $(0.09: 1)$ than tops (functional leaves; Supplementary Figure 1). In corn, Ciampitti and Vyn (2014) documented a more balanced $\mathrm{N}: \mathrm{P} \quad(5: 1)$ and $\mathrm{N}: \mathrm{K}$ (1:1) ratios under high-yielding environments. In a review analysis, Sadras (2006) showed consistent N:P ratio differences among grain crops, 4:1 for oilseed, 6:1 for cereal, and 9:1 for legume. Similar N:P ratio, 5:1 units, was synthesized by Ciampitti and Vyn (2014), in a historical and global analysis performed for corn crop. On the opposite side, dry leaves (less functional tissues) presented the largest N:P ratio, 18:1 units 
(ranging from 6:1 to 51:1 units; Figure 4D). Sugarcane yield influence was not clearly individualized for the N:P ratio of dry leaves, but lower nutrient content was observed in this plant component with a larger reduction on $\mathrm{P}$ (fivefold) in relation to $\mathrm{N}$ (twofold) when compared with the tops organ (Figures 4B,C). A higher $\mathrm{N}: \mathrm{P}$ ratio in dry leaves is explained by the remobilization of nucleic-acid $\mathrm{P}$ to young leaves and the lower P demand of mature tissues (Usuda, 1995; Güsewell, 2004).

A balanced nutrient approach is critical to sustain functional tissues and to promote $\mathrm{C}$ fixation, growth, and increase sugar content in the sugarcane production (Allison et al., 1997, 2007; Zhao et al., 2014). From our study, nutrient content have a broad range of variability related to stalk yield levels (Table 3 ). For example, aboveground $\mathrm{N}, \mathrm{P}$, and $\mathrm{K}$ contents ranged from 117-280, 16-50, and 233-560 $\mathrm{kg} \mathrm{ha}^{-1}$, respectively, from low $\left(\leq 80 \mathrm{Mg} \mathrm{ha}^{-1}\right)$ and high yielding sites (>160 $\left.\mathrm{Mg} \mathrm{ha}^{-1}\right)$, respectively. Nutrient internal efficiencies can be described as the ability of a plant to transform nutrients acquired from all sources (e.g., soil, fertilizer, and atmosphere) into economic yield (Cassman et al., 2002; Dobermann, 2007; Ciampitti and Vyn, 2014), in this case represented as sugarcane yield. The higher values of NIE found in low-yielding environments represents a dilution of that nutrient in the plant, and is related to its deficiency. In contrast, low values of NIE observed in highyielding environments represent an accumulation of that nutrient in the plant, and two hypothesis may explain this pattern, as follows: to (1) a restriction in its internal utilization due to other limiting factors; and (2) an excessive uptake (also termed as "luxury consumption") of $\mathrm{K}$, beyond the amount required for stalk production (Setiyono et al., 2010). Similar results as obtained in this investigation were reported by Setiyono et al. (2010) and Ciampitti et al. (2013) for corn, with lowest NIEs as the crop was reaching high-yield potential. The RIE values reported here are (Table 3) similar but higher from those documented by Silva and Casagrande (1983) and Gopalasundaram et al. (2012), which ranged from $0.56-1.20 \mathrm{~kg}$ $\mathrm{N}, 0.13-0.35 \mathrm{~kg}$ P, and $0.6-1.9 \mathrm{~kg} \mathrm{~K}$ per $\mathrm{Mg}$ of stalk produced. Lower nutrient requirements presented in previous studies are associated to low yield levels, coupled to interactions among genotype, environment, and management (Dias et al., 1999; Thorburn et al., 2011; Gopalasundaram et al., 2012). From the soil perspective, nutrient availability can limit crop acquisition, thus leading to lower biomass and stalk production (Table 1, Figure 3). In high productivity systems, fertilization of N, P, and $\mathrm{K}$ is essential to replenish stalk nutrient removal in order to sustainably maintain high yield levels. Therefore, soil test remains as a powerful diagnostic tool to quantify nutrient availability and subsequent fertilizer needs (McCray et al., 2014). In Brazil, however, $\mathrm{N}$ recommendation for sugarcane is based on the target yield concept (Cantarella et al., 1998), where soil $\mathrm{N}$ supply, the main source of $\mathrm{N}$ to the crop (Franco et al., 2011), is entirely neglected. Thus, a soil testing capable to predict in situ $\mathrm{N}$ mineralization in sugarcane fields is critically needed.

In summary, nutrient ratios can provide useful information for sugarcane growers as related to understanding crop nutrient balances and improving fertility diagnosing systems. To extend of our knowledge, this study is the first one in synthesizing data in nutrient ratios and yield potential for sugarcane crop. A main constraint on this analysis is related to when the data was collected, all at harvest time, which it did not allow the utilization of this information for in-season fertility management. A temporal analysis on nutrient ratios involving multiple inseason sampling times is needed in order to provide timely information on nutrient management recommendations for sugarcane crop. Future research should be focus on connecting soil and plant processes for identifying the main factors not only affecting nutrient ratios but also their relationship to the yield and plant biomass components.

\section{CONCLUSION}

Seasonal biomass accumulation presented three growth phases (lag, exponential-linear, and stationary) during the ratoon growing season. In overall, improvement in stalk yields was tightly connected to superior aboveground biomass accumulation. Additionally, high yielding sugarcane was correlated with higher nutrient content, more balanced and narrowed nutrient ratios, and higher efficiency in producing each unit of stalk per unit of nutrient accumulated. The nutrient partitioning evaluation portrayed lower nutrient ( $\mathrm{N}, \mathrm{P}$, and $\mathrm{K}$ ) content in the dry leaves fraction but with a high $\mathrm{N}: \mathrm{P}$ ratio relative to the top plant component. Greater sugarcane yield and narrowed $\mathrm{N}: \mathrm{P}$ ratio $(6: 1)$ were documented for tops fraction as $\mathrm{N}$ and $\mathrm{P}$ content increased.

Stalk yield gap can be closed by better balancing nutrient ratios that can be achieved by better understanding complex plant-soil pathways related to nutrient uptake and plant utilization. This synthesis analysis not only provides a descriptive summary on the variation of nutrient ratios at harvest at varying sugarcane yield levels, but also established a foundational concept on investigating nutrient ratios by dissecting plant components. From a pragmatic standpoint, further research is needed for integrating the replacement concept in decision nutrient management support tools for assisting sugarcane producers on the farming decision-making process.

\section{AUTHOR CONTRIBUTIONS}

Conceived and designed the experiments: JL, IC, EM, MV-M, and PT. Performed the experiments under field conditions: JL, EM, MV-M, and PT. Performed the laboratory analyzes: JL. Contributed reagents, materials, and analysis tools: PT. Analyzed the data: JL and IC. Wrote the paper: JL, IC, EM, and PT. All the authors revised the paper.

\section{FUNDING}

The São Paulo Research Foundation (FAPESP) granted scholarships to JL, EM, and MV-M (Processes n. 2011/21532-5, 2009/04691-2, and 2009/10192-9, respectively). This research was funded by the National Council for Scientific and 
Technological Development (CNPq; Process n. 574982/2008-6), Yara International ASA, and Agrolatino Biotecnologia S.A. This research was partially supported (JL's support at K-State) by funds from Department of Agronomy and Kansas State Research and Extension. This is contribution no. 16-283-J from the Kansas Agricultural Experiment Station.

\section{ACKNOWLEDGMENTS}

We are grateful to São Martinho Group, Abengoa Bioenergia, and Agropastoril Paschoal Campanelli for their logistical support. We thank José A. Forti, Hugo H. Batagello, Henrique C. J. Franco, Carlos E. Faroni, and André C. Vitti for their assistance with the field work. We thank reviewers for their constructive comments.

\section{REFERENCES}

Adami, M., Rudorff, B. F. T., Freitas, R. M., Aguiar, D. A., Sugawara, L. M., and Mello, M. P. (2012). Remote sensing time series to evaluate direct land use change of recent expanded sugarcane crop in Brazil. Sustainability 4, 574-585. doi: 10.3390/su4040574

Allison, J. C. S., Pammenter, N. W., and Haslam, R. J. (2007). Why does sugarcane (Saccharum sp. hybrid) grow slowly? S. Afr. J. Bot. 73, 546-551. doi: 10.1016/j.sajb.2007.04.065

Allison, J. C. S., Williams, H. T., and Pammenter, N. W. (1997). Effect of specific leaf nitrogen content on photosynthesis of sugarcane. Ann. Appl. Biol. 131, 339-350. doi: 10.1111/j.1744-7348.1997.tb05160.x

Amaral, L. R., and Molin, J. P. (2013). The effectiveness of three vegetation indices obtained from a canopy sensor in identifying sugarcane response to nitrogen. Agron. J. 106, 273-280. doi: 10.2134/agronj 2012.0504

Andersson, A., Johansson, E., and Oscarson, P. (2005). Nitrogen redistribution from the roots in post-anthesis plants of spring wheat. Plant Soil 269, 321-332. doi: 10.1007/s11104-004-0693-6

AOAC International (2006). Official Methods of Analysis of AOAC International. Arlington: AOAC International.

Beaufils, E. R., and Sumner, M. E. (1976). Application of the DRIS approach for calibrating soil, plant yield and plant quality factors of sugarcane. Proc. S. Afr. Sugar Tech. Assoc. 50, 118-124.

Bell, M. J., and Garside, A. L. (2005). Shoot and stalk dynamics and the yield of sugarcane crops in tropical and subtropical Queensland, Australia. Field Crops Res. 92, 231-248. doi: 10.1016/j.fcr.2005.01.032

Britto, D. T., and Kronzucker, H. J. (2002). NH4+ toxicity in higher plants: a critical review. J. Plant Physiol. 159, 567-584. doi: 10.1078/0176-16170774

Cantarella, H., van Raij, B., and Quaggio, J. A. (1998). Soil and plant analyses for lime and fertilizer recommendations in Brazil. Commun. Soil Sci. Plant Anal. 29, 1691-1706. doi: 10.1080/00103629809370060

Cardozo, N. P., and Sentelhas, P. C. (2013). Climatic effects on sugarcane ripening under the influence of cultivars and crop age. Sci. Agric. (Piracicaba, Brazil) 70, 449-456.

Cassman, K. G., Dobermann, A., and Walters, D. T. (2002). Agroecosystems, nitrogen-use efficiency, and nitrogen management. Ambio 31, 132-140. doi: 10.1579/0044-7447-31.2.132

Ciampitti, I. A., Camberato, J. J., Scott, T., and Vyn, T. J. (2013). Maize nutrient accumulation and partitioning in response to plant density and nitrogen rate: I. Macronutrients. Agron. J. 105, 783-795. doi: 10.2134/agronj2012. 0467

Ciampitti, I. A., and Vyn, T. J. (2012). Physiological perspectives of changes over time in maize yield dependency on nitrogen uptake and associated nitrogen efficiencies: a review. Field Crops Res. 133, 48-67. doi: 10.1016/j.fcr.2012. 03.008

\section{SUPPLEMENTARY MATERIAL}

The Supplementary Material for this article can be found online at: http://journal.frontiersin.org/article/10.3389/fpls.2016.00466

FIGURE S1 | Relationships between nitrogen (N) versus potassium (K) content for all plant components: aboveground biomass (A), dry leaves (B), tops (C), and stalks (D). Each data point represents an individual field plot at sugarcane harvest of a first ratoon growing season for three site-years $(n=102)$. Dotted lines show boundary ratios for each component between $\mathrm{N}$ versus $\mathrm{K}$, and black line shows the average value.

TABLE S1 | Mean value of biomass accumulation, nutrient (N, P, and K) content, and nutrient ratios (N:P and N:K) in the stalks, dry leaves, tops, and total aboveground part of sugarcane (first ratoon cycle) across three sites located in the Southeast region of Brazil ( $n=4$ for Sites 1 and $2 ; n=5$ for Site 3).

Ciampitti, I. A., and Vyn, T. J. (2014). Understanding global and historical nutrient use efficiencies for closing maize yield gaps. Agron. J. 106, 2107-2117. doi: 10.2134/agronj14.0025

Coale, F. J., Sanchez, C. A., Izuno, F. T., and Bottcher, A. B. (1993). Nutrient accumulation and removal by sugarcane grown on everglades histosols. Agron. J. 85, 310-315. doi: 10.2134/agronj1993.000219620085000 20028x

Dias, F. L. F., Mazza, J. A., Matsuoka, S., Perecin, D., and Maule, R. F. (1999). Produtividade da cana-de-açúcar em relação a clima e solos da região noroeste do estado de são Paulo. Rev. Bras. Cienc. Solo 23, 627-634. doi: 10.1590/S010006831999000300016

Dobermann, A. (2007). Nutrient use Efficiency - Measurement and Management in Fertilizer Best Management Practices: General Principles, Strategies for Adoption and Voluntary Initiatives vs Regulations. Papers presented at the IFA International Workshop, Brussels, 1-28.

Donaldson, R. A., Redshaw, K. A., and van Rhodes, R. A. (2008). Season effects on productivity of some commercial South African sugarcane cultivars. I: Biomass and radiation use efficiency. P. S. Afr. Sug. 81, 517-527.

Epstein, E., and Bloom, A. J. (2005). Mineral Nutrition of Plants: Principles and Perspectives. Sunderland: Sinauer Associates Inc.

Fortes, C., Trivelin, P. C. O., Vitti, A. C., Otto, R., Franco, H. C. J., and Faroni, C. E. (2013). Stalk and sucrose yield in response to nitrogen fertilization of sugarcane under reduced tillage. Pesqui. Agropec. Bras. 48, 88-96. doi: 10.1590/S0100204X2013000100012

Franco, H. C. J., Otto, R., Faroni, C. E., Vitti, A. C., Oliveira, E. C. A., and Trivelin, P. C. O. (2011). Nitrogen in sugarcane derived from fertilizer in Brazilian field conditions. Field Crops Res. 121, 29-41. doi: 10.1016/j.fcr.2010. 11.011

Franco, H. C. J., Otto, R., Vitti, A. C., Faroni, C. E., Oliveira, E. C. A., Fortes, C., et al. (2015). Residual recovery and yield performance of nitrogen fertilizer applied at sugarcane planting. Sci. Agric. (Piracicaba, Brazil) 72, 528-534. doi: 10.1590/0103-9016-2015-0170

Gava, G. J. D. C., Trivelin, P. C. O., Vitti, A. C., and Oliveira, M. W. (2005). Urea and sugarcane straw nitrogen balance in a soil-sugarcane crop system. Pesqui. Agropec. Bras. 40, 689-695. doi: 10.1590/S0100-204X2005000 700010

Gee, G. W., and Bauder, J. W. (1986). "Particle-size analysis," in Methods of Soil Analysis: Physical and Mineralogical Methods, ed. A. Klute (Madison, WI: ASA and SSSA), 383-411.

Gopalasundaram, P., Bhaskaran, A., and Rakkiyappan, P. (2012). Integrated nutrient management in sugarcane. Sugar Technol. 14, 3-20. doi: 10.1007/s12355-011-0097-x

Groot, C. C., Marcelis, L. F. M., Boogard, R. V. D., Kaiser, W. M., and Lambers, H. (2003). Interaction of nitrogen and phosphorus in determining growth. Plant Soil 248, 257-268. doi: 10.1023/A:1022323215010

Güsewell, S. (2004). N:P ratios in terrestrial plants: variation and functional significance. New Phytol. 164, 243-266. doi: 10.1111/j.1469-8137.2004.01192.x 
Inman-Bamber, N. G., Muchow, R. C., and Robertson, M. J. (2002). Dry matter partitioning of sugarcane in Australia and South Africa. Field Crops Res. 76, 71-84. doi: 10.1016/S0378-4290(02)00044-8

IPNI (2015). Evolução do Consumo Aparente de N, P, K e total de NPK no Brasil. Available at: http://brasil.ipni.net/article/BRS-3132 [Accessed 29 May, 2015].

Kingston, G. (2014). “Mineral nutrition of sugarcane,” in Sugarcane: Physiology, Biochemistry, and Functional Biology, eds P. H. Moore and F. C. Botha (Oxford: John Wiley \& Sons), 85-120.

Leal, M. R. L. V., Galdos, M. V., Scarpare, F. V., Seabra, J. E. A., Walter, A., and Oliveira, C. O. F. (2013). Sugarcane straw availability, quality, recovery and energy use: a literature review. Biomass Bioenerg. 53, 11-19. doi: 10.1016/j.biombioe.2013.03.007

Lim, P. O., Kim, H. J., and Nam, H. G. (2007). Leaf senescence. Annu. Rev. Plant Biol. 58, 115-136. doi: 10.1146/annurev.arplant.57.032905.105316

Machado, E. C., Pereira, A. R., Fahl, J. I., Arruda, H. V., and Cione, J. (1982). Índices biométricos de duas variedades de cana-de-açúcar. Pesqui. Agropec. Bras. 17, 1323-1329.

Mariano, E., Leite, J. M., Megda, M. X. V., Ciampitti, I. A., Vitti, A. C., Faroni, C. E., et al. (2016). Biomass and nutrient content by sugarcane as affected by fertilizer nitrogen sources. Crop Sci. doi: 10.2135/cropsci2015.06. 0349

Mariano, E., Leite, J. M., Megda, M. X. V., Torres-Dorante, L., and Trivelin, P. C. O. (2015). Influence of nitrogen form supply on soil mineral nitrogen dynamics, nitrogen uptake, and productivity of sugarcane. Agron. J. 107, 641-650. doi: 10.2134/agronj14.0422

Mariano, E., Trivelin, P. C. O., Leite, J. M., Megda, M. X. V., Otto, R., and Franco, H. C. J. (2013). Incubation methods for assessing mineralizable nitrogen in soils under sugarcane. Rev. Bras. Cienc. Solo 37, 450-461. doi: 10.1590/S010006832013000200016

McCray, J. M., Morgan, K. T., Baucum, L., and Ji, S. (2014). Sugarcane yield response to nitrogen on sand soils. Agron. J. 106, 1461-1469. doi: 10.2134/agronj13.0513

Meyer, J. H. (1981). An evaluation of DRIS based on leaf analysis for sugarcane in South Africa. Proc. S. Afr. Sugar. Tech. Assoc. 55, 1-8.

Mitchell, R. D. J., Thorburn, P. J., and Larsen, P. (2000). Quantifying the loss of nutrients from the immediate area when sugarcane residues are burnt. Proc. Aust. Soc. Sugar Cane Technol. 22, 206-211.

Nelson, D. W., and Sommers, L. E. (1996). “Total carbon, organic carbon and organic matter," in Methods of Soil Analysis: Chemical Methods, ed. D. L. Sparks (Madison, WI: ASA and SSSA), 961-1010.

Oliveira, E. C. A. (2011). Balanço Nutricional da Cana-de-Açúcar Relacionado à Adubação Nitrogenada, Ph.D. dissertation University of São Paulo, Piracicaba. Available at: http://www.teses.usp.br/teses/disponiveis/11/11140/ tde-20042011-094249/en.php [accessed 30 April, 2015].

Oliveira, E. C. A., Freire, F. J., Oliveira, R. I., Freire, M. B. G. S., Neto, D. E. S., and Silva, M. A. S. (2010). Extração e exportação de nutrientes por variedades de cana-de-açúcar cultivadas sob irrigação plena. Rev. Bras. Cienc. Solo 34, 1343-1352. doi: 10.1590/S0100-06832010000 400031

Otto, R., Mulvaney, R. L., Khan, S. A., and Trivelin, P. C. O. (2013). Quantifying soil nitrogen mineralization to improve fertilizer nitrogen management of sugarcane. Biol. Fert. Soils 49, 893-904. doi: 10.1007/s00374-0130787-5

Prado, R. M., and Pancelli, M. A. (2008). Resposta de soqueiras de cana-de-açúcar à aplicação de nitrogênio em sistema de colheita sem queima. Bragantia 67, 951-959. doi: 10.1590/S0006-87052008000400018

Rae, A. L., Grof, C. P. L., Casu, R. E., and Bonnett, G. D. (2005). Sucrose accumulation in the sugarcane stem: pathways and control points for transport and compartmentation. Field Crops Res. 92, 159-168. doi: 10.1016/j.fcr.2005.01.027

Rakkiyappan, P., Thangavelu, S., Bhagyalakshmi, K. V., and Radhamani, R. (2007). Uptake of nitrogen, phosphorus and potassium by soma promising mid late maturing sugarcane clones. Sugar Technol. 9, 21-27. doi: 10.1007/BF0 2956909

Resende, A. S., Xavier, R. P., Oliveira, O. C., Urquiaga, S., Alves, B. J. R., and Boddey, R. M. (2006). Long-term effects of pre-harvest burning and nitrogen and vinasse applications on yield of sugar cane and soil carbon and nitrogen stocks on a plantation in Pernambuco, N.E. Brazil. Plant Soil 281, 339-351. doi: 10.1007/s11104-005-4640-y

Ridesa (2010). Catálogo Nacional de Variedades "RB” de Cana-de-Açúcar. Curitiba: Ridesa. Available at: http://canaufv.com.br/catalogo/catalogo-2010.pdf [Accessed 25 January, 2016].

Rossato, J. A. S., Costa, G. H. G., Madaleno, L. L., Mutton, M. J. R., Higley, L. G., and Fernandes, O. A. (2013). Characterization and impact of the sugarcane borer on sugarcane yield and quality. Agron. J. 105, 643-648. doi: 10.2134/agronj2012.0309

Sadras, V. O. (2006). The N:P stoichiometry of cereal, grain legume and oilseed crops. Field Crops Res. 95, 13-29. doi: 10.1016/j.fcr.2005. 01.020

Schultz, N., Lima, E., Pereira, M. G., and Zonta, E. (2010). Efeito residual da adubação na cana-planta e da adubação nitrogenada e potássica na cana-soca colhidas com e sem a queima da palhada. Rev. Bras. Cienc. Solo 34, 811-820. doi: 10.1590/S0100-0683201000030 0023

Setiyono, T. D., Walters, D. T., Cassman, K. G., Witt, C., and Dobermann, A. (2010). Estimating maize nutrient uptake requirements. Field Crops Res. 118, 158-168. doi: 10.1016/j.fcr.2010.05.006

Shukla, S. K., Yadav, R. L., Singh, P. N., and Singh, I. (2009). Potassium nutrition for improving stubble buds sprouting, dry matter partitioning, nutrient uptake and winter initiated sugarcane (Saccharumspp. hybrid complex) ratoon yield. Eur. J. Agron. 30, 27-33. doi: 10.1016/j.eja.2008. 06.005

Silva, L. C. F., and Casagrande, J. C. (1983). “Nutrição mineral da cana-de-açúcar," in Nutrição e Adubação da Cana-de-açúcar no Brasil, ed. J. Orlando Filho (Piracicaba: IAA and PLANALSUCAR), 77-99.

Spironello, A., van Raij, B., Penatti, C. P., Cantarella, H., Morelli, J. L., Orlando Filho, J., et al. (1997). "Outras culturas industriais," in Recomendações de Adubação e Calagem para o Estado de São Paulo, eds B. van Raij, H. Cantarella, J. A. Quaggio, and A. M. C. Furlani (Campinas: Instituto Agronômico), 237239.

Soil Survey Staff (2014). Keys to Soil Taxonomy. Washington, DC: USDA and Natural Resources Conservation Service.

Tasso Júnior, L.C. (2007). Caracterização agrotecnológica de cultivares de canade-açúcar (Saccharum spp.) na região centro-norte do Estado de São Paulo, Ph.D. dissertation University Estadual Paulista Júlio de Mesquita Filho Jaboticabal. Available at: http://www.fcav.unesp.br/download/pgtrabs/pv/d/ 1357.pdf [accessed 20 January 2016].

Thorburn, P. J., Biggs, J. S., Webster, A. J., and Biggs, I. M. (2011). An improved way to determine nitrogen fertilizer requirements of sugarcane crops to meet global environmental challenges. Plant Soil 339, 51-67. doi: 10.1007/s11104010-0406-2

Trivelin, P. C. O., Franco, H. C. J., Otto, R., Ferreira, D. A., Vitti, A. C., Fortes, C., et al. (2013). Impact of sugarcane trash on fertilizer requirements for São Paulo, Brazil. Sci. Agric. (Piracicaba, Braz.) 70, 345-352. doi: 10.1590/S010390162013000500009

UNICA (2015). São Paulo Fecha Safra 2013/2014 com Colheita Mecanizada em $83 \%$ dos Canaviais. Available at: http://www.unica.com.br/noticia/65515849 20310621254/sao-paulo-fecha-safra-2013-por-cento2F2014-com-colheita-mec anizada-em-83-por-cento-dos-canaviais/ [accessed 22 July, 2015].

Urquiaga, S., Xavier, R. P., Morais, R. F., Batista, R. B., Schultz, N., Leite, J. M., et al. (2012). Evidence from field nitrogen balance and $15 \mathrm{~N}$ natural abundance data for the contribution of biological N2 fixation to Brazilian sugarcane varieties. Plant Soil 356, 5-21. doi: 10.1007/s11104-0111016-3

Usuda, H. (1995). Phosphate deficiency in maize. V. Mobilization of nitrogen and phosphorus within shoots of young plants and its relationship to senescence. Plant Cell Physiol. 36, 1041-1049.

van Heerden, P. D. R., Donaldson, R. A., Watt, D. A., and Singels, A. (2010). Biomass accumulation in sugarcane: unravelling the factors underpinning reduced growth phenomena. J. Exp. Bot. 61, 2877-2887. doi: 10.1093/jxb/erq144

van Raij, B., Andrade, J. C., Cantarella, H., and Quaggio, J. A. (2001). Análise Qquímica Para Avaliação da Fertilidade de Solos Tropicais. Campinas: InstitutoAgronômico. 
Vieira-Megda, M. X., Mariano, E., Leite, J. M., Franco, H. J. C., Vitti, A. C., Megda, M. M., et al. (2015). Contribution of fertilizer nitrogen to the total nitrogen extracted by sugarcane under Brazilian field conditions. Nutr. Cycl. Agroecosys. 101, 241-257. doi: 10.1007/s10705-015-9676-7

Wood, A. W., Muchow, R. C., and Robertson, M. J. (1996). Growth of sugarcane under high input conditions in tropical Australia. III. Accumulation, partitioning and use of nitrogen. Field Crops Res. 48, 223-233. doi: 10.1016/S0378-4290(96)00043-3

Zhao, D., Glaz, B., and Comstock, J. C. (2014). Physiological and growth responses of sugarcane genotypes to nitrogen rate on a sand soil. J. Agron. Crop Sci. 200, 290-301. doi: 10.1111/jac.12084
Conflict of Interest Statement: The authors declare that the research was conducted in the absence of any commercial or financial relationships that could be construed as a potential conflict of interest.

Copyright (c) 2016 Leite, Ciampitti, Mariano, Vieira-Megda and Trivelin. This is an open-access article distributed under the terms of the Creative Commons Attribution License (CC BY). The use, distribution or reproduction in other forums is permitted, provided the original author(s) or licensor are credited and that the original publication in this journal is cited, in accordance with accepted academic practice. No use, distribution or reproduction is permitted which does not comply with these terms. 